\title{
Bacterial endophytes: An agroecological alternative in the growth promotion and plant health management of cabbage leaf (Brassica oleracea var. acephala)
}

\author{
Endófitos bacterianos: Uma alternativa agroecológica na promoção de crescimento e no manejo \\ fitossanitário de couve folha (Brassica oleracea var. acephala) \\ Endófitos bacterianos: una alternativa agroecológica en la promoción del crecimiento y manejo
}

fitosanitario de la hoja de couve (Brassica oleracea var. acephala)

Received: 02/04/2021 | Reviewed: 02/07/2021 | Accept: 02/11/2021 | Published: 02/18/2021

\author{
Clayton dos Santos Silva \\ ORCID: https://orcid.org/0000-0003-3924-5526 \\ Universidade Federal de Pernambuco, Brazil \\ E-mail: clayton@live.pt \\ Romário Guimarães Verçosa de Araújo \\ ORCID: https://orcid.org/0000-0001-6150-9829 \\ Universidade Federal de Alagoas, Brazil \\ E-mail: romariorgva@hotmail.com \\ Jessé Rafael Bento de Lima \\ ORCID: https://orcid.org/0000-0003-3439-8697 \\ Universidade Federal de Pernambuco, Brazil \\ E-mail: jesserafael.adm@hotmail.com \\ Luigi Canário Cabral e Sousa \\ ORCID: https://orcid.org/0000-0002-9301-545X \\ Universidade Federal de Pernambuco, Brazil \\ E-mail: luiggi.agronomia@gmail.com \\ Paula Cibelly Vilela da Silva \\ ORCID: https://orcid.org/0000-0003-2157-4698 \\ Universidade Federal de Alagoas, Brazil \\ E-mail: paulacibelly17@gmail.com \\ Tania Marta Carvalho dos Santos \\ ORCID: https://orcid.org/0000-0002-1816-7840 \\ Universidade Federal de Alagoas, Brazil \\ E-mail: tmcs@ceca.ufal.br \\ Jakes Halan de Queiroz Costa \\ ORCID: https://orcid.org/0000-0002-0018-9646 \\ Universidade Federal de Alagoas, Brazil \\ E-mail: jakes.jakes@gmail.com \\ João Manoel da Silva \\ ORCID: https://orcid.org/0000-0002-7654-5475 \\ Universidade Federal de Alagoas, Brazil \\ E-mail: joao.manoel@iqb.ufal.br
}

\begin{abstract}
Among the most economically significant agricultural crops, the species of the Brassicaceae family stand out as one of the most popular in human food. Cabbage leaf (Brassica oleracea var. acephala) is an essential ingredient in many regional dishes and is an excellent nutritional source for children, young and old. However, Brazilian production has been suffering from the incidence of pests and diseases that affect the crop, being the black rot of the cruciferous (BRC), the main cause of economic losses of its producers. Given this context, the objective is to build a theoretical framework by reviewing the literature on the agroecological management of BRC in cabbage leaf, based on the contribution of scientific knowledge to the preservation of agrobiodiversity in rural and traditional family communities.
\end{abstract}

Keywords: Phytotechnics; Black rot of crucifers; Biological control; Ecological management.

\section{Resumo}

Dentre as culturas agrícolas de maior expressividade econômica, as espécies da família Brassicaceae destacam-se como uma das mais populares na alimentação humana. A couve-manteiga (Brassica oleracea var. acephala) é um ingrediente essencial em diversos pratos regionais, sendo uma excelente fonte nutricional para crianças, jovens e idosos. Entretanto, a produção brasileira vem sofrendo com a incidência de pragas e doenças que acometem a lavoura, 
sendo a podridão negra das crucíferas (PNC), a principal causa de perdas econômicas de seus produtores. Diante deste contexto, objetiva-se a construção de um arcabouço teórico mediante revisão de literatura sobre o manejo fitotécnico e fitossanitário agroecológico de cultivares de couve comum, na premissa de agregar ao conhecimento científico ecológico na preservação da agrobiodiversidade em comunidades familiares rurais e tradicionais.

Palavras-chave: Fitotecnia; Podridão negra das crucíferas; Controle biológico; Manejo ecológico.

\section{Resumen}

Entre los cultivos agrícolas de mayor importancia económica, la especie de la familia Brassicaceae se destaca como una de las más populares en la alimentación humana. La hoja de col (Brassica oleracea var. acephala) es un ingrediente esencial en muchos platos regionales y es una excelente fuente nutricional para niños, jóvenes y mayores. Sin embargo, la producción brasileña viene sufriendo la incidencia de plagas y enfermedades que afectan al cultivo, siendo la podredumbre negra de las crucíferas (PNC), la principal causa de pérdidas económicas de sus productores. Ante este contexto, el objetivo es construir un marco teórico mediante la revisión de la literatura sobre el manejo agroecológico de PNC en hoja de col, basado en el aporte del conocimiento científico a la preservación de la agrobiodiversidad en comunidades familiares rurales y tradicionales.

Palabras clave: Fitotecnia; Podredumbre negra de crucíferas; Control biológico, Manejo ecológico.

\section{Introdution}

With high economic, sociocultural and political relevance for the country, horticulture drives the development of rural and traditional communities (Avila, 2017), the generation of jobs and income (Gazolla \& Schneider, 2017) and the provision of quality food for consumption in schools, hospitals, restaurants and homes, contributing to the production chain and the supply of basic necessities. However, in recent decades, phytosanitary problems have been the object of study in teaching and research institutions in Brazil and the world, to the detriment of the incidence of pests and diseases that affect the most varied cultures, whether of agricultural, zootechnical, pharmacological or forestry, responsible for numerous substantial losses in the Brazilian agricultural sector.

Constituting one of the most important botanical families for rural family units, the Brassicaceae family (Cruciferae), known for grouping conventional food species such as cabbage (Brassica oleracea var. Capitata), broccoli (B. oleracea var. Italica), radish (Raphanus sativus), arugula (Eruca sativa), cauliflower (B. oleracea) and common cabbage (B. oleracea var. Acephala)(Santos, 2000; Carvalho \& Clemente, 2004), it is also used in popular medical systems, decorations and landscape projects and in the production of vegetable oils and fats, used for food and bioenergetic purposes. However, some pathologies such as spots, wilting, mosaics, rot and rust attract attention and care in their management before and after planting.

Among the most common bacterioses in crucifers, black rot crucifers (BRC), disseminated by the phytopathogen Xanthomonas campestris pv. campestris (Pammel) Dowson (Xcc), stands out for the severity of its injuries, which can cause leaf necrosis and in more severe cases, the total senescence of the plant (Maringoni, 1997; Bedendo, 2011).

Its main host is the common cabbage, a leafy with a mild climate with distribution throughout the national territory and great acceptance by the consumer market, integrating the ranking of the 50 most commercialized vegetable species in the country, according to data published by EMBRAPA in 2010.

Due to the increased use of agrochemicals in the management of crops and the scarcity of sustainable and ecological interventions to promote plant growth and to control BRC and other plant diseases, biological control (biocontrol) appears in an alternative way. use of biological agents (fungi, viruses, bacteria and nematodes) in crop phytotechnical and phytosanitary management, generating less impact on the environment, maintaining the balance of agricultural systems and local agrobiodiversity.

Therefore, the objective of this work was to develop a literature review on agroecological management by means of bacterial endophytes to promote growth and resistance to BRC in cabbage leaf plants, as a technical-scientific contribution to the preservation of Brazilian agrobiodiversity. 


\section{Methodology}

This article was developed according to the methodological principles of narrative review. The bibliographic survey was carried out from scientific and informational materials now published on national and international official and periodical documents on search platforms, as well as through specialized books through the use of keywords related to the object that helped in the information filtering. complementary in the premise of building a theoretical framework that focuses on the contextualization of the central research problem.

Marconi and Lakatos (2020) clarify that bibliographic research is a type of research that covers all bibliography made public in relation to the subject matter of study, from single publications such as books, monographs, dissertations, theses and articles in periodicals such as audiovisual materials and cartographic. This type of research tends to build a theoretical or methodological framework that helps in future research as a way of consulting, guiding or confronting future results (Pereira et al. 2018).

\section{The Cabbage Leaf Crop}

Cabbage leaf (Brassica oleraceae L. var. acephala) has its center of diversity pointed out by researchers to the Mediterranean, Asia Minor and Western European Coast region (Balkaya \& Yanmaz, 2005), primary ancestor wild kale. Its introduction in Brazil took place from the entry of propagating material brought by Portuguese navigators during the colonial period (Madeira et al., 2008).

These vegetable is a typical herbaceous with a mild or cold climate (between $16-22{ }^{\circ} \mathrm{C}$ ), with an annual or biennial cycle (Novo et al., 2010) and with an upright size, reaching approximately 40 to $120 \mathrm{~cm}$ in height, presenting simple leaves, light green, long petiole, limbus and well-developed ribs and rosy phyllotaxis around its stem (Filgueira, 2013).

Currently, the species is one of the most popular in human food (Santos, 2000; Carvalho \& Clemente, 2004), consumed in its fresh form or as an ingredient in various dishes, such as juices, soups, salads and stews (Santos et al., 2017), being a vegetable rich in proteins, carbohydrates, fibers, iron, phosphorus, sulfur, calcium, vitamins $\mathrm{A}, \mathrm{C}$ and $\mathrm{K}$, thiamine, riboflavin, ascorbic acid and carotenoids (Filgueira, 2013), which they give it healing and anti-cancer properties (Moreno et al., 2006), as well as preventive against ophthalmic and intestinal diseases (Lefsrud et al., 2007; Trani et al., 2015).

The culture has been maintained over the years by Brazilian family farming due to its easy of cultivation and management, and it can be propagated through the "sexed" way, through the use of vigorous seeds or through the "asexual" way, through the planting of healthy seedlings. In Brazil, the main method used by horticulturists is vegetative propagation, with the formation of seedlings from the buds that appear in the leaf axils in most commercialized cultivars. Hybrid cabbages do not produce sprouts, being propagated through seeds (Trani et al., 2015).

According to Trani et al. (2015), the use of 128-cell plastic trays is recommended for vegetative propagation, and unconventional (alternative) materials such as plastic bags and newspapers (5 to $6 \mathrm{~cm}$ in diameter and 10 to $15 \mathrm{~cm}$ in height) can also be used, with commercial substrate of pine, coconut fiber or soil rich in organic matter.

The preference for the consumer market is for flat leaf cultivars and old clones. These clones, more traditional in Goiás, São Paulo and Minas Gerais are known, indistinctly, as "butter" type. There are dozens of these clones with wide genetic variation. Seed producing companies have brought improved cultivars to the market, including some hybrids. However, these cultivars do not have characteristics required by the consumer market. However, some of these hybrids produce large, wavy and soft leaves, with good productivity (Filgueira, 2013).

Butter kale is considered to be rustic when compared to other crucifers, including nutritional requirements. Organic fertilization helps to establish the culture, especially if it is carried out before transplantation, incorporated into the furrow. In 
poor soils it is recommended to apply boron (B), in the form of borax $\left(\mathrm{Na}_{2}\left[\mathrm{~B}_{4} \mathrm{O}_{5}(\mathrm{OH})_{4}\right] \cdot 8 \mathrm{H}_{2} \mathrm{O}\right)$. In low or medium fertility soils, it is recommended to apply macronutrients such as nitrogen $(\mathrm{N})$, phosphorus $(\mathrm{P})$ and potassium $(\mathrm{K})$ in the furrow during seedling transplantation (Filgueira, 2013).

Leaf kale, in general, does not usually present physiological anomalies, therefore, it can be seen symptoms of deficiency of the molybdenum micronutrient (Mo) in the form of large holes in the leaf blade, quite similar to the damage caused by caterpillars. In this case, it is recommended to apply the micronutrient in the form of sodium molybdate $\left(\mathrm{Na}_{2} \mathrm{MoO}_{4}\right)$ (Filgueira, 2013).

The farmer, as an implanter and manager, must always be attentive in relation to climatic conditions and the specific water need, since the water deficit causes the flabbiness of the plant cells, visually externalizing the wilting of the plant, being able, together with the excessive sunstroke, causing drastic burns on leaves and buds, causing the death of cultivated plants and partial or total loss of production (Trani et al., 2015).

In relation to irrigation, variables such as the rainy and growing season, crop cycle, soil type, slope of the land, drainage capacity, daily water retention and daily sunshine are crucial for good crop planning. The irrigation systems that can be adopted in the cultivation of cabbage are: furrows, by sprinkling, dripping and micro-sprinkling (Trani et al., 2015). According to Filgueira (2013), the leaf kale/cabbage is highly demanding in water, and constant irrigation must be carried out, with the sprinkler system being the most recommended for the crop, as itimprove leaf quality, as well as control aphids and caterpillars. The level of useful water in the soil must be kept close to $100 \%$ of the field capacity.

In addition, it is recommended to carry out a mulch cover with rice husks, cereal stalks or dry grass. During the long period of harvest, in order to stimulate the formation of new leaves on the main stem, it is advisable to prune and eliminate old leaves (Filgueira, 2013). According to Trani et al. (2015), the use of plastic mulching is an excellent technique for weed control, improving soil water retention and the conservation of native microbiota. However, if the farmer does not have the possibility to make the investment, weed control is recommended by means of superficial weeding, in order to simply brush the weeds, being careful not to cause damage to the roots.

Its planting, therefore, must be carried out in moist, but well-drained soil with good availability of organic matter ( $\mathrm{pH}$ between 5.5-6.5) (Filgueira, 2013; Trani et al., 2015), to avoid emergence of weeds in the area, in addition to injuries caused by pests and diseases that can cause the decimation of culture in the field (Mathias \& Melo, 2015). Spacing of 80 to $100 \mathrm{~cm}$ between rows by 50 to $70 \mathrm{~cm}$ between plants is recommended (the vast majority of Brazilian farmers adopt cultivation in single lines, however in some regions of Brazil you can find cultivation in double rows, with spacing 80 to $100 \mathrm{~cm}$ between double lines and 40 to $50 \mathrm{~cm}$ between single lines), which may differ according to the type of cultivation, soil, topography and specific characteristics of the cultivar adopted (Trani et al., 2015), where post-management planting is characterized as an essential factor for the establishment of the stand and the success of the harvest, which ends 80-90 days after planting (Shingo \& Ventura, 2009).

The best method of harvesting is to "pull down" the well-developed leaves, breaking them at the point of insertion with the stem, without leaving part of the petiole close to the stem. The most demanding consumer markets prefer sheets with a size of 25 to $30 \mathrm{~cm}$ in length, large and lush, light colored, in the case of the Minas Gerais market, or dark colored, for São Paulo consumers. (Filgueira, 2013).

Cultivated throughout Brazil, commercial production is concentrated in the south-central region of the country, where an estimated area of 6,128 hectares of cultivated kale is estimated (Vilela \& Luengo, 2017), with emphasis on the states of São Paulo, Rio de Janeiro and Minas Gerais, largest production hubs of culture, respectively (Wruck et al., 2010).

In 2006, Brazil produced around 93,551 tonnes (t) of cabbage, with the Northeast being the second largest producer in the country $(19,700 \mathrm{t})$, behind only the Southeast region, which was responsible for the national production of 56,000 $\mathrm{t}$. 
For the commercialization of vegetables, several physical and sensory attributes are evaluated by the producers and their respective consumers, aspects that help to ensure the receptivity of the food by the market, such as appearance, size, shape, brightness and color of the leaf (Novo et al ., 2010). However, some pests and diseases directly interfere with the quality of the product, generating economic losses for the farmer and the consequent reduction in the quantity offered in markets, supermarkets and open markets (Silva et al., 2019).

Among the main pests that cause imminent damage to cabbage leaf and other crucifers, the aphids (Brevicoryne brassicae (Linnaeus, 1758)) and Myzus persicae (Sulzer, 1776) stand out; whitefly Bemisia tabaci (Genn., 1889); curuquerê (Ascia monuste orseis (Latr., 1819); Crucifer moth (Plutella xylostella (L., 1875)); threaded (Agrotis epsilon) caterpillar (Hufnagel, 1767); palm-spanner (Trichoplusia ni (Hueb., 1802)I and cabbage borer (Hellula phidilealis (Walker, 1859)) (Gallo et al., 2002).

The main diseases that affect its cultivation are alternaria (Alternaria brassicae), fusariose (Fusarium oxysporum $\mathrm{f}$. Sp. Conglutinans); hernia of the crucifers (Plasmodiophora brassicae); downy mildew (Peronospora parasitica); soft rot (Erwinia carotovora var. carotovoa) and black rot (Xanthomonas campestris pv. campestris) (ABCSEM, 2015; Trani et al., 2015), this being the most important disease of brassica (Williams, 1980) and the main target phytopathological research on cabbage culture (Wruck et al., 2010).

\section{Etiological Agent of the Black Rot of Crucifers (BRC)}

Bacteria of the genus Xanthomonas (from the Greek "xanthus" = yellow, "monas" = unit) (Bradbury, 1984) are considered the most important group of plant pathogens of agricultural species (Leyns et al., 1984) when dealing with bacteria (it is estimated that there are more than 100 plant pathogens combined in this genus) (Bedendo, 2011), with each existing plant on the planet, at least one xanthomone as an etiologic agent of diseases, mainly in the aerial part (Marcuzzo, 2009).

In according to the phylogenetic classification, the genus Xanthomonas belongs to the phylum Proteobacteria, class Gammaproteobacteria, and Xanthomonadales order, and the Xanthomonadaceae family (Dowson, 1939; Garrity \& Holt, 2000), creplaced by 20 species (X. albilineans, X. arboricola, X. axonopodis, X. bromi, X. campestris, X. cassavae, X. codiaei, X. cucurbitae, X. fragariae, X. hortorum, X. hyacinthi, X. melonis, X. oryzae, X. pisi, X. populi, X. sacchari, X. theicola, X. translucens, X. vasicola e X. vesicatoria) (Takatsu, 2000).

Among that, the specie campestris, stand out like the most complex and with the higher number of patovares (pv.), subdivided into approximately 140 (Bradbury, 1984), differing from injured host and tissue (Tessmann, 2002).

Since the beginning of the 20th century, the group has been the target of intense taxonomic and phylogenetic studies, being described for the first time in 1921, as a pathogen in tomato cultivars (Solanum lycopersicum), and chili (Capsicum spp.). However, the English phytopathologist Walter John Dowson, in 1939, proposed the reclassification of phytopathogenic bacteria in four distinct genera: Bacterium (in 1953 the generic name started to be considered invalid, being the species belonging to the same redistributed among the genera Pectobacterium and Erwinia), Pseudomonas and Xanthomonas (Dowson, 1949; Garrett, 1981), where, the ability to provoke diseases and consequent damages in different cultures of agronomic interest, made the study of this class of infectious microorganisms more in-depth and applied to solve problems in the field (Leite Júnior, 1990).

Lately, the genus has been responsible for countless losses in agricultural production worldwide (Quezado-Duval \& Lopes, 2010), due to diseases such as leaf spots (Marcolin et al., 2015), necrotic stem lesions , leaves and fruits (Aiello et al., 2013), withered (Almeida et al., 2014), cancers (Moraes et al., 2011), among other symptoms, infecting a range of approximately 400 plant species, such as rice (Oryza sativa), bean (Phaseolus vulgaris), grape (Vitis vinifera), mango (Mangifera indica), passionfruit (Passiflora edulis), cassava (Manihot esculenta), cotton (Gossypium hirsutum), tomato 
(Solanum lycopersicum), potato (Solanum tuberosum), wheat (Triticum aestivum), neem (Azadirachta indica), citrus and crucifers (Leyns et al., 1984).

The black rot of the crucifers (PNC), first described in 1889 (Maji \& Nath, 2015), is a disease that affects species of the Brassicaceae family, among them, the cabbage leaf (Maringoni, 1997). Caused by the bacterial phytopathogen Xanthomonas campestris pv. campestris (Pammel) Dowson (Xcc), the BRC has generated considerable losses in the productivity and health of the food consumed, where, it is estimated a $60 \%$ decrease in production due to the disease (Dzhalilov \& Tiwari, 1995).

In Brazil, bacteriosis has caused a reduction in the commercial value of the crop, with cases of incidence of the disease throughout the national territory, mainly in the states of Amazonas, Amapá, Bahia, Goiás, Pernambuco, Paraná, Rio Grande do Sul, Sergipe and the Federal District (Malavolta Júnior et al., 2008).

Its etiologic agent is characterized as a yellowish, mobile and uniflagellate gram-negative (Elrod \& Braun, 1947), arranged in the form of bacilli (rod-like cell appearance), with aerobic respiratory metabolism and the formation of nonsporogenic colonies of medium size (0.4-0.7 x 0.7-1.6 $\mu \mathrm{m})$, with a smooth, circular and shiny surface, with an optimal growth temperature (incubation) between $28-30^{\circ} \mathrm{C}$ (Andrade et al., 2005) and complex circular structure (Bradbury, 1984).

The main generic characteristic that differentiates this group of pathogens from the others is the synthesis of an extracellular polysaccharide (EPS) (Sutherland, 1993) with a gummy (viscous) consistency (Pan et al., 2000), obtained during the growth process bacterial in culture medium, called xanthomonadine (aryl-polyene-brominated) (Bradbury, 1986), popularly known as xanthan gum, used by the food, agricultural, pharmaceutical, chemical and oil industries (Rosalam \& England, 2006).

Xcc survives in soil and plant debris (in association or not), weeds, remaining diseased plants and propagation materials, lodging inside or on its surface, acquiring an epiphytic characteristic.

Its dissemination can occur over short and long distances, through environmental interference, such as splashing rainwater and irrigation by the incidence of strong winds or by interference from human action, through the transport of sick seeds and seedlings or by using of infected tools during crop management, favoring the inoculation of bacteria in cabbage plants (Maringoni, 1997).

After the penetration of the pathogen by hydatodes (leaf structures responsible for the secretion of excess water through the gutation process, being the main portal of entry of the causal agent in crucifers) (Reis \& Olivares, 2006), the bacteria in suspension colonize the xylem vessels, causing the darkening of their tissues (vascular discoloration) (Hugouvieux et al., 1998), inducing the development of cuneiform lesions on the leaf edges, as yellowish "V" shaped damage (main characteristic symptom of species). In addition to this injury, other structural symptoms are expressed as underdevelopment, wilt, necrosis, burning and premature leaf fall and rotting of infected plants (Maringoni, 1997; Bedendo, 2011).

Due to the vulnerability of vegetables to attack by the harmful agent, new management alternatives have been adopted to facilitate the diagnosis and control of the BRC (Núñez, 2015). Producers are recommended to use propagating materials of good origin and to disinfect machinery, equipment and utensils that can become vectors of the pathogen, infecting healthy plants and spreading the disease. In addition to these practices, the use of resistant cultivars and hybrids (genetic control), plowing in the planting area, the elimination of crop residues and crop rotation (cultural control), the heat treatment of seeds at high temperatures (control physical) and the use of antagonistic microorganisms (biological control) (Maringoni, 1997), can also help in reducing the severity of Xcc and in strengthening agroecological practices in family production. 


\section{Agroecological Pratices from Crop Prodution}

In the mid of 1970 years, a new model of agriculture was imposed in Brazil, aimed at increasing food production through the implementation of new technologies in the national field, such as the use of pesticides, chemical fertilizers, hybrid seeds, agricultural mechanization, among others (Barros, 2010), a process of rural modernization known worldwide as "Green Revolution" (Tybusch \& Martins, 2016).

However, despite the drastic increase in productivity in the short term, the Green Revolution caused numerous political, social and environmental upheavals in the country, such as increased concentration of income and dependence on production technologies, indebtedness of farmers and consequently the rural exodus, pollution and degradation of natural resources and ecosystems, reduction of genetic diversity, in addition to inducing resistance to agrochemicals in different pests and diseases (Serra et al., 2016).

Faced with this political-social scenario, a model of agricultural production contrary to that established by the technological package emerges, through the adoption of sustainable agricultural and social practices, called Agroecology (Mercadante \& Almeida, 2019). "Alternative agriculture", as it is also known, establishes human relations as one of the main foundations of construction, in addition to respect for the work performed, the rational use of resources and the preservation of genetic biodiversity and the local socio-cultural identity (Lima et al ., 2018), rescuing the social function of the land and the values of community agriculture.

Green manure, crop rotation, the use of adapted propagules and Creole seeds, the sustainable management of water and soil, the biomineralization of compounds, the application of biofertilizers and alternative pest and disease control are some of the practices of agroecological management most widespread around the world (Zanuncio Junior et al., 2018), techniques, which are appropriate as tools to raise awareness of the irrational use of synthetic resources that compromise the balance and maintenance of agro-ecosystems and regional agrobiodiversity.

For exactly 10 years, Brazil has occupied the first position in the world ranking of consumption of artificial chemical substances, such as herbicides, insecticides, bactericides, fungicides, nematicides, acaricides (Porto, 2018), being cabbage leaf, one of the most common species contaminated by the excessive use of these molecules in the crop, together with chili (Capsicum annuum), strawberries (Fragaria spp.), cucumbers (Cucumis sativus), lettuce (Lactuca sativa), carrots (Daucus carota), pineapples (Ananas comosus), beet (Beta vulgaris), papaya (Carica papaya) and tomatoes (Solanum lycopersicum), according to a list released by ANVISA in 2018.

In this context, the biocontrol of plant diseases is based on the introduction and management of agents called antagonists, which play the role of controlling infectious organisms, aiming at reducing the activity of the causative agent in the host, providing ecological and population balance in the host. agricultural system (Mathre, Cook \& Callan, 1999).

The main antagonistic interactions between two species are antibiosis (ability to synthesize antibiotics), competition (ability to occupy infection sites of the etiologic agent) and parasitism (ability to nourish themselves from other microorganisms) (Bedendo, Massola Júnior \& Amorim, 2011).

The application of bacterial endophytes as biological control agents (BCA) is shown to be a promising tool in the alternative control of phytodeseases, since in addition to cellular protection, these bacteria also help in the fixation of atmospheric nitrogen $\left(\mathrm{N}_{2}\right)$ (Boddey \& Dobereiner, 1995), in the solubilization of inorganic phosphates (Silva et al., 2018) and in the supply of nutrients, phytohormones and growth regulators (Silva et al., 2018), offering plant protection against desiccation and attack by pests (biological control of insects) (Garcia et al., 2015) and diseases (antagonism to phytopathogens), also acting as growth promoters (Azevedo, 1998; Montaldo, 2016). 
From the numerous symbiotic activities associated with endophytic bacteria, the mechanism of antagonism to plant pathogens emerges to reduce the impacts caused by human interference in the environment (Bedendo et al., 2011), contrasting the then model of land exploitation by Brazilian agribusiness.

\section{Endophytic Bacteria: Biocontrolers Agents}

During the evolutionary process, the plants developed mechanisms of adaptation to their habitat and evolved for their survival (Peixoto Neto et al., 2004), in parallel, the microorganisms associated with these plants also suffered adaptations that gave them tolerance to environments with low water availability and the ability to protect plants against certain environmental adversities (Kavamura et al., 2013).

These microorganisms are classified as endophytic, as they inhabit the interior of plants, usually their aerial parts, without causing damage to the host (Hallmann et al., 1997; Moreira \& Siqueira, 2006), a characteristic that differs from microphytopathogenic organisms (Azevedo, 1998), which cause damage to plants, being reflected in their organs or metabolism.

The first mention of the existence of endophytic bacteria and fungi occurred in 1866, with the studies of the German scientist Heinrich Anton de Bary, who distinguished this class of microorganisms from plant pathogens. However, it was only at the end of the 1970 years, when its pharmacological, biotechnological and plant growth promotion properties attracted the attention of researchers worldwide, that studies and subsequent discoveries gained emphasis and notoriety in the scientific community (Azevedo, 1998; Santos \& Varavallo, 2011).

It is believed that all the plants on the planet have associated microorganisms (it is estimated that there are more than 1,000,000 different species), and a given plant may host more microbial species than others, indicating the great biodiversity of fungi and endophytic bacteria on all continents (Petrini, 1991; Strobel \& Daisy, 2003; Amatuzzi, 2014). This group is classified according to its occurrence in a given host, where, the most frequently encountered species are classified as dominant, in contrast, the most scarce (rare) species are called secondary (Azevedo, 1998).

The main ways of penetration of endophytic bacteria occur through the presence of natural openings (stomata, nectaries, lenticels, hydatodes and floral openings) or wounds (injuries, broken trichomes, emergence of lateral roots and wounds) (Reis \& Olivares, 2006) because, unlike fungi, they do not have structures that allow direct penetration into their host, such as appressors and enzymatic mechanisms, therefore requiring some "involuntary" opening to start the process of colonizing plant tissues (Goodman, 1982).

The main genera of bacterial endophytes already described in the literature are Acetobacter, Acinetobacter, Actinomyces, Agrobacterium, Azospirillum, Bacillus, Burkholderia, Curtobacterium, Pantoea, Pseudomonas, and Xanthomonas (Hallmann et al., 1997; Peixoto Neto et al., 2002), found mainly in cotton (Gossypium hirsutum), potato (Solanum tuberosum), beet (Beta vulgaris), common and sweet corn (Zea mays) and in several types of citrus (Azevedo, 1998). This set of hosts forms the group of plant species with the highest number of associated bacteria reported to date.

Several authors report the success of using this class of endophytes in the control of phytopathogens, such as some bacteria of the genus Erwinia (soy symbionts), commonly used for the control of Pseudomonas syringae pv. glycinea, the etiological agent of the "bacterial burning of soy" (Volksch et al., 1992); the endophyte Bacillus pumilus, which in a study by Nicole Benhamou in 1996, promoted the induction of resistance in microbiolized pea plants (Pisum sativum) to Fusarium oxysporum f. sp. pisi, stimulating physiological defense mechanisms against the spread of the pathogen in the host's plant cells; in rice culture (Oryza sativa), numerous associated strains showed antifungal properties against Guamannomyces graminis, Heterobasidium annosum, Pythium myriotylum and Rhizoctonia solani, infectious microorganisms of agricultural and forest species (Mukhopadhyay et al., 1996), with more examples in literature that reinforce the efficiency of biological control of plant diseases by endophytic bacteria. 
All these mechanisms of action (direct and indirect) help in the success of production, providing the establishment, protection and development of the most different agricultural cultures in the world (Peixoto Neto et al., 2002; Luz et al., 2006).

\section{Endophytic Bacteria: Plant Growth Promoters}

Endophytic microorganisms have the potential to promote growth for several cultivable species (Araújo et al., 2019). Melo et al. (2015) found in arugula plants that isolates of actinomycetes promoted an increase in agronomic variables such as height, number of leaves, diameter of the stem, phytomass and dry matter, in addition to promoting resistance to attack by pathogenic microorganisms throughout the plant structure. This growth promotion can happen through numerous ways, one of which is the antagonistic power to phytopathogens or the production of phytohormones. Several authors have reported the efficiency of actinomycetes in the control of pathogenic microorganisms. Castillo-Fabela et al. (2001) found the efficiency of actinomycetes antagonistic to Rhizoctonia solani.

The examples of endophytic bacteria that have the capacity to promote growth are diverse in the literature, including common food species such as tomatoes (Bashan et al., 1989), lettuce (Freitas et al., 2003), arugula (Melo et al. , 2015), sugarcane (Montaldo, 2016), passion fruit (Silva et al., 2018; Silva et al., 2019), among others.

This growth promotion in the receiving plant may be the result of several ecological, biological and physiological mechanisms, such as: biocontrol by competition for nutrients with causal agents (Silva et al., 2015); phytohormone production, such as auxin (Bianco et al., 2006), ethylene (Glick et al., 1995), cytokinins and growth regulators (Silva et al., 2018); also by increasing the availability of nutrients by fixing atmospheric nitrogen (Antoun et al., 1998), or even by solubilizing inorganic phosphates (Silva et al., 2018).

According to Venieraki et al. (2010), these microorganisms mobilize insoluble inorganic phosphates, from a mineral matrix of the soil, so that they can be absorbed by the plant's root system, nourishing it. This activity, therefore, reduces the $\mathrm{pH}$ of the soil. Manjula and Podile (2005), when studying the growth promotion caused by Bacillus subtilis, found that the main benefits of inoculation would be the increase in nitrogen fixation, the solubilization of nutrients, the synthesis of phytohormones and subsequent physical-chemical improvements in the soil. In addition, there was an increase in resistance to stresses and environmental interventions and against the activity of injury-promoting organisms.

Drought tolerance, one of the most studied mechanisms for promoting plant growth by teaching and research institutions, occurs through various mechanisms of cell protection, such as the production of exopolysaccharides (EPS) (Nocker et al., 2012) and the formation biofilm (Silva et al., 2019).

Exopolysaccharides (EPS) are defined as extracellular polysaccharides that are found attached to the surface of cells or excreted into the medium (Seesuriyachan et al., 2012). The production of EPS by microorganisms in direct interaction with plants, helps the survival of the plant under conditions of extreme stress, such as in situations of water scarcity or restriction, high salinity and by considerable temperature variations According to Barreto et al. (2011), EPS provide free life to the bacteria, allowing adherence and microbial colonization on solid surfaces, the involvement of cell membranes against desiccation and the fixation of nutrients close to the bacteria.

In contrast, biofilm is defined as a biological matrix with bacterial populations adhering to each other, which is composed of extracellular carbohydrates, proteins and even DNAs (Montaldo, 2016). According to Boari et al. (2009), biofilm is another mechanism of tolerance to water stress, consisting of bacterial communities surrounded by substances exuded by the bacteria themselves, being free when released from the bacterial community, with the advantage of protecting against external aggressions, such as the lack of nutrients and to desiccation.

The endophyte-plant relationship can help in the success of production in the field, both for its mechanism of growth promotion, as well as for the protection offered against pests and phytopathogens and the abiotic effects that can cause certain 
stresses to the plant. Therefore, the use of these microorganisms in agriculture, can be considered an ecological and sustainable tool for the farmer to replace or decrease the use of chemical products in the crops and thus guarantee a clean, renewable and sustainable production, without compromising the health of the food produced and consumed, finally, bringing more health and quality of life to the table of the worker and his family.

\section{Conclusion}

Still inexpressive, research and scientific contributions are initial and introductory in relation to other hardwoods (lettuce, cabbage and arugula) and other agricultural crops of greater economic significance (sugar cane, corn and soy), with data restriction. updated production and information on species-specific sustainable management, a major obstacle to mapping and taking strategies to establish agroecological cultivation of leaf kale as an effective source of income for family farming, rescuing the function of the land in preserving agrobiodiversity and native and adapted genetic resources.

\section{Acknowledgment}

The authors thank the National Council for Scientific and Technological Development (CNPq) for the financial support.

\section{References}

ABCSEM - Associação Brasileira do Comércio de Sementes e Mudas. (2015). Manual Técnico para cultivo de hortaliças. Terceira edição, Campinas, São Paulo, Brasil, 54p.

Aiello, D., Scuderi, G., Vitale, A., Firrao, G., Polizzi, G. \& Cirvilleri, G. A. (2013). Pith necrosis caused by Xanthomonas perforans on tomato plants. European Journal of Plant Pathology, 137, 29-41.

Almeida, I. M. G., Rodrigues, L. M. R., Beriam, L. O. S. (2014). Xanthomonas fuscans subsp. fuscans causing wilt symptoms in bean plants (Phaseolus vulgaris) in Brazil. Arquivos do Instituto Biológico, 20 (10), 1-3.

Amatuzzi, R. F. (2014). Fungos endofíticos do morangueiro e potencial de controle biológico de duponchelia fovealis zeller (lepidoptera: crambidae). Dissertarion (Master Degree) Universidade Federal do Paraná. Curitiba, Paraná, Brasil. 52p.

Antoun, H., Beauchamp, C. J., Goussard, N., Chabot, R. \& Lalande, R. (1998). Potencial of Rhizobium and Bradyrhizobium species as plant growth promoting rhizobacterian on non-legumes: Effect on radishes (Raphanus sativus L.). Plant \& Soil, 204, 57-67.

ANVISA - Agência Nacional de Vigilância Sanitária. (2018). Programa de Análise de Resíduos de Agrotóxicos em Alimentos - PARA. http://portal.anvisa.gov.br/programa-de-analise-de-registro-de-agrotoxicos-para

Araújo, R. G. V., Silva, C. S., Santos, T. M. C., Lima, J. R. B., Montaldo, Y. C., Abreu, L. A., Silva, A. B., Araújo Júnior, J. V. \& Silva, J. M. (2019). Potential of endophytic bacteria of the Bacillus genus to Brassica oleracea var. acephala growth promotion. Asian Academic Research Journal of Multidisciplinary, 6 (3), 53-61.

Avila, S. R. (2017). A influência da adubação orgânica na preferência alimentar de Brevicoryne brassicae (Homoptera: Aphididae) em Brassica oleracea var. acephala (Brassicaceae). Dissertation (Master Degree), Universidade Federal De Pelotas. Pelotas, Rio Grande do Sul, Brasil. 62p.

Azevedo, J. L. (1998). Microrganismos endofíticos. In: Melo, I. S. \& Azevedo, J. L. [eds.]. Ecologia microbiana. 486, Embrapa-CNPMA, Jaguariúna, São Paulo, Brasil.

Balkaya, A., \& Yanmaz, R. (2005). Promising kale (Brassica oleracea var. acephala) populations from Black Sea region, Turkey. New Zealand Journal of Crop and Horticultural Science, 33, 1-7.

Barreto, M. C. S., Figueiredo, M. V. B., Burty, H. A., Silva, M. L. R. B. \& Lima-Filho, J. L. (2011). Produção e comportamento reológico de biopolímeros produzidos por rizóbios e caracterização genética. Revista Brasileira Agrociência, 17 (2/4), 221-227.

Barros, B. (2010). Há 40 anos, DDT precipitou restrições. Valor Econômico, São Paulo, São Paulo, Brasil.

Bashan, Y., Singh, M. \& Levanony, H. 1989. Contribution of Azospirillum brasilienses Cd to growth of tomato seedling is not through nitrogen fixation. Canadian Journal of Botany, 67 (8), 2429-2434.

Bedendo, I. P. (2011). Bactérias fitopatogênicas. In: Manual de fitopatologia: Princípios e conceitos. [S.l: s.n.]. Editora Agronômica Ceres, São Paulo, São Paulo, Brasil. 
Bedendo, I. P., Massola Júnior, N. S. \& Amorim, L. (2011). Controles cultural, físico e biológico de doenças de plantas. In: Amorim, L., Rezende, J. A. M. \& Bergamin Filho, A. [eds.]. Manual de fitopatologia: Princípios e conceitos. 1, 4, 367-388, Editora Agronômica Ceres, São Paulo, São Paulo, Brasil.

Bianco, C., Imperlini, E., Calogero, R., Senatore, B., Amoresano, A., Carpentieri, A., Pucci, P. \& Defez, R. (2006). Indole-3-acetic acid improves Escherichia coli's defences to stress. Archives of Microbiology, 185, 373-282.

Boari, C. A., Alves, M. P., Tebaldi, V. M. R., Savian, T. V. \& Piccoli, R. H. (2009). Biofilm formation by Aeromonas hydrophila and Staphylococcus aureus on stainless steel using milk and different conditions of cultivation. Ciência e Tecnologia de Alimentos, 29 (4), 886-895.

Boddey, R. M. \& Dobereiner, J. (1995). Nitrogen fixation associated with grasses and cereals: recent results and pespectives for the future research. Fertilizers Research, 42 (1), 241-250.

Bradbury, J. F. (1986). Guide to plant pathogenic bacteria. Slough. Editora CAB International Mycological Institute. 332p.

Bradbury, J. F. (1984). Xanthomonas Dowson (1939). In: Bergey, D. H., Krieg, N. R. \& Holt, J. C. [eds.]. Bergey's Manual of Systematic Bacteriology. 1, 199-210.

Carvalho, P. T. C. \& Clemente, E. (2004). Qualidade de brócolis (Brassica oleracea var. itálica) em embalagem com atmosfera modificada. Acta Scientiarum, 26, 497-502.

Castillo-Fabela, E., Gallegos-Morales, G., Hernández-Castillo, F. D., Cepeda-Siller, M. \& Zamora-Villa, V. M. (2001). Efectividad de actinomicetos aislados de la rizosfera de papa sobre Rhizoctonia solani Kuhn in vitro. Revista Mexicana de Fitopatologia, 19 (2), $203-207$.

Costerton, J. W., Lewandowski, Z., Caldwell, D. E., Korber, D. R. \& Lappin-Scott, H. M. (1995). Microbial biofilms. Annual Review of Microbiology, 49, 711-745.

Dowson, W. J. 1949. Manual of bacterial plant diseases. Adam \& Charles Black, Londres, Inglaterra.

Dowson, W. J. (1939). On the systematic position and generic names of the gramnegative bacterial plant pathogens. Zentralblatt fur Bakteriologie, Parasitenkunde und Infektions Krankheiten, 2 (100), 177-93.

Dzhalilov, F. S. \& Tiwari, R. D. (1995). Soil and cabbage plant debris as infection sources of black rot. Archive für Phytopathologie und Pflanzenschutz, 29, 383-387.

Elrod, R. P. \& Braun, A. C. (1947). Serological studies of the genus Xanthomonas. I-cross-agglutination relationships. Journal of Bacteriology, 53 (5), 509518.

EMBRAPA - Empresa Brasileira de Pesquisa Agropecuária. (2010). Catálogo brasileiro de hortaliças: Saiba como plantar e aproveitar 50 das espécies mais comercializadas no país. Embrapa Hortaliças: Brasília, Distrito Federal, Brasil, 59p.

Filgueira, F. A. R. (2013). Novo Manual de Olericultura: Agrotecnologia moderna na produção e comercialização de hortaliças. Editora UFV, Viçosa, Minas Gerais, Brasil, terceira edição.

Freitas, S., Melo, A. M. T. \& Donzeli, V. P. (2003). Promoção de crescimento de alface por rizobactérias. Revista Brasileira de Ciência do Solo, 27, 61-70.

Gallo, D., Nakano, O., Silveira Neto, S., Carvalho, R. P. L., Baptista, G. C., Berti Filho, E., Parra, J. R. P., Zucchi, R. A., Alves, S. B., Vendramim, J. D., Marchini, L. C., Lopes, J. R. S. \& Omoto, C. (2002). Entomologia Agrícola. FEALQ, Piracicaba, São Paulo, Brasil.

Garcia, T. V., Knaak, N. \& Fiuza, L. M. (2015). Bactérias endofíticas como agentes de controle biológico na orizicultura. Arquivos do Instituto Biológico, 82, $1-9$.

Garrett, S. D. (1981). Pioneer leaders in plant pathology: W. J. Dowson. Annual Review of Phytopathology, 19, 29-34.

Garrity, G. M. \& Holt, J. G. (2000). An overview of the road map to the manual. Systematic Bacteriology.

Gazolla, M. \& Schneider, S. (2017). Cadeias curtas e redes agroalimentares alternativas: Negócios e mercados da Agricultura Familiar. Editora da UFRGS, Porto Alegre, Rio Grande do Sul, Brasil.

Glick, B. R. (2005). Modulation of plant ethylene levels by the bacterial enzyme ACC deaminase. FEMS Microbiology Letters, 251 , 1-7.

Goodman, R. N. (1982). The infection process. In: Mount, M. S.; Lacy, G. H. [eds.]. Phytopathogenic prokaryotes. 1, 31-62, Academic Press, Nova York.

Hallmann, J., Quadt-Hallmann, A., Mahaffee, W. F. \& Kloepper, J. W. (1997). Bacterial endophytes in agricultural crops. Canadian Journal of Microbiology, 43, 895-914.

Hugouvieux, V., Barber, C. E. \& Daniels, M. J. (1998). Entry of Xanthomonas campestris pv. campestris into hydathodes of Arabidopsis thaliana leaves: A system for studying early infection events in bacterial pathogenesis. Molecular Plant-Microbe Interactions, 11 (6), $537-543$.

Kavamura, V. N., Santos, S. N., Silva, J. L., Parma, M. M., Ávila, L. A., Visconti, A. \& Melo, I. S. (2013). Screening of Brazilian cacti rhizobacteria for plant growth promotion under drought. Microbiological Research, 168, 183-191.

Marconi, M. A., Lakatos, E. M. Fundamentos de metodologia científica. (2020). Atlas.

Lefsrud, M., Kopsell, D., Wenzel, A. \& Sheehan, J. (2007). Chances in kale (Brassica oleracea L. var. acephala) carotenoid and chlorophyll pigment concentrations during leaf ontogeny. Scientia Horticulturae, 112, 136-141. 
Leite Júnior, R. P. (1990). Cancro Cítrico: Prevenção e controle no Paraná. Circular 61 do Instituto Agronômico do Paraná - IAPAR. Londrina, Paraná, Brasil, $51 \mathrm{p}$.

Leyns, F., De Cleene, M., Swings, J. \& De Ley, J. (1984). The host range of the genus Xanthomonas. Botanical Review, 50 (3), 308-356.

Lima, J. R. B., Silva, C. S., Silva, J. O. L., Sousa, L. C. C., Santos, E. L. S., Cristo, C. C. N., Lima, A. K. X., Moura, R. O., Aldabalde, J. C., Cardoso, F. A., Junqueira, M. E. L. \& Gaião, W. D. C. (2018). Seminário de construção do XVI ERA Nordeste: A união do movimento estudantil na construção da Agroecologia no Nordeste Brasileiro. Revista Craibeiras de Agroecologia, 1 (1), 1-10.

Luz, J. S., Silva, R. L. O., Silveira, E. B. \& Cavalcante, U. M. T. (2006). Atividade enzimática de fungos endofíticos e efeito na promoção do crescimento de mudas de maracujazeiro-amarelo. Revista Caatinga, 19 (2), 128-134.

Madeira, N. R., Reifschneider, F. V. B. \& Giordano, L. B. (2008). Contribuição portuguesa à produção e ao consumo de hortaliças no Brasil: uma revisão histórica. Horticultura Brasileira, 26 (4), 428-432.

Maji, A. \& Nath, R. (2015). Pathogenecity test by using different inoculation methods on Xanthomonas campestris pv. campestris caused of black rot of cabbage. International Journal of Research in Applied, Natural and Social Sciences, 3, 53-58.

Malavolta Júnior, V. A.; Beriam, L. O. S., Almeida, I. M. G., Rodrigues Neto, J. \& Robbs, C. F. (2008). Bactérias fitopatogênicas assinaladas no Brasil: Uma atualização. Summa Phytopathologica, 34, 1-88.

Manjula, K. \& Podile, A. R. (2005). Icrease in seedling emergence and dry weight of pigeon pea in the field with chitin-supplemented formulations of Bacillus subtilis AF 1. World Journal of Microbiology and Biotechnology, 21, 1057-1062.

Marcolin, G., Carmo, A. L. M. \& Garcia, F. A. O. (2015). Biocontrole in vitro de mancha foliar bacteriana do eucalipto, mediado por rizobactérias. Centro Científico Conhecer, 11 (21), 346-354.

Marcuzzo, L. L. (2009). Aspectos epidemiólogicos de sobrevivência e de ambiente no gênero Xanthomonas. Ágora: Revista de Divulgação Científica, 16 (1), $13-19$.

Maringoni, A. C. (1997). Doenças das Crucíferas. In: Kimati, H., Amorim, L., Resende, J. A. M., Bergamin Filho, A. \& Camargo, L. E. A. [eds.]. Manual de Fitopatologia: Doenças das Plantas Cultivadas. Editora Agronômica Ceres, São Paulo, São Paulo, Brasil.

Mathias, J. \& Melo, R. A. C. (2015). Como plantar couve. Globo Rural. http://revistagloborural.globo.com/vida-na-fazenda/comoplantar/noticia/2015/05/como-plantar-couve.html

Mathre, D. E.; Cook, R. J.; Callan, N. W. 1999. From discovery to use: Traversing the world of commercializing biocontrol agents for plant disease control. Plant Disease, 83, 972-983. 10.1094/PDIS.1999.83.11.972

Melo, A. L. S.; Silva, J. M.; Moreira Neto, A.; Santos, T. M. C. 2015. Prospecção e isolamento de actinomicetos com potencial para promoção de crescimento em rúcula (Eruca sativa L.). Revista Verde, 10, 3, 31-34. 10.18378/rvads.v10i3.3317

Mercadante, P. T. M. \& Almeida, R. A. (2019). Reforma Agrária e Transição Agroecológica: Experiências de sustentabilidade no assentamento 20 de março em Três Lagoas/MS. Revista NERA, 22, 111-139.

Montaldo, Y. C. (2016). Bioprospecção e isolamento de bactérias associadas à cana-de-açúcar (Saccharum officinarum L.) com características para a promoção de crescimento vegetal. Doctoral Theis, Universidade Federal de Alagoas. Rio Largo, Alagoas, Brasil. 101p.

Moraes, W. B., Jesus Junior, W. C., Peixoto, L. A., Moraes, W. B. \& Cecílio, R. A. (2011). Mapeamento das áreas de risco de ocorrência do cancro cítrico no Brasil. Centro Científico Conhecer, 7 (12), 1-10.

Moreira, F. M. S. \& Siqueira, J. O. (2006). Microbiologia e Bioquímica do solo. Editora UFLA, Lavras, Minas Gerais, Brasil.

Moreno, D. A., Carvajal, M., Lopezberenguer, C. \& Garcia-Viguera, C. (2006). Chemical and biological characterization of nutraceutical compounds of broccoli. Journal Pharmaceutical and Biomedical Analysis, 41, 1508-22.

Mukhopadhyay, N. K., Garrison, N. K., Hinton, D. M., Bacon, C. W., Khush, G. S., Peck, H. D. \& Datta, N. (1996). Identification and characterization of bacterial endophytes of rice. Mycopathologia, 134 (3), 151-159.

Nocker, A., Fernández, P. S., Montijn, R. \& Schuren, F. (2012). Effect of air drying on bacterial viability: a multiparameter viability assessment. Journal of Microbiological Methods, 90, 86-95.

Novo, M. C. S. S., Prela-Pantano, A., Trani, P. E. \& Blat, S. F. (2010). Desenvolvimento e produção de genótipos de couve manteiga. Horticultura Brasileira, 28 (3), 321-325.

Núñez, A. M. P. (2015). Produtos alternativos controlam a podridão negra e aumentam a atividade de enzimas ligadas à defesa em couve. Dissertation (Master Degree), Universidade Federal de Lavras. Lavras, Minas Gerais, Brasil. 61p.

Pan, A., Moreira, A. S. \& Vendruscolo, C. T. (2000). Efeito da concentração inicial do inóculo no crescimento celular e qualidade de biopolímeros de Xanthomonas campestris pv. pruni cepa 06. Revista Brasileira de Agrociência, 6 (3), 273-277.

Peixoto Neto, P. A. S., Azevedo, J. L. \& Araújo, W. L. (2002). Microrganismos endofíticos. Revista Biotecnologia Ciência \& Desenvolvimento, $29,62-77$.

Pereira, A. S., Shitsuka, D. M., Pereira, F. J. \& Shitsuka, R. (2018). Metodologia da Pesquisa Científica. UAB, Santa Maria.

Petrini, O. (1991). Fungal endophyte of tree leaves. In: Andrews, J. \& Hirano, S. S. [eds.]. Microbial Ecology of Leaves. 179-197, Springer Verlag. 
Porto, M. F. S. (2018). O trágico pacote do veneno: Lições para a sociedade e a Saúde Coletiva. Cadernos de Saúde Pública, 34 (7), e00110118.

Quezado-Duval, A. M. \& Lopes, C. A. (2010). Mancha bacteriana: uma atualização para o Sistema de Produção Integrada de Tomate Indústria. Circular Técnica 84, Embrapa Hortaliças. Brasília, Distrito Federal, Brasil, 24p.

Reis, V. M. \& Olivares, F. L. (2006). Vias de penetração e infecção de plantas por bactérias. Embrapa Agrobiologia. Seropédica, Rio de Janeiro, Brasil, 34p.

Rosalam, S. \& England, R. (2006). Review of xanthan gum production from unmodified starches by Xanthomonas campestris sp. Enzyme and Microbial Technology, 39 (2), 197-207.

Santos, M. A. C. (2000). Caracterização química das folhas de brócoli e couve-flor (Brassica oleracea L.) para utilização na alimentação humana. Dissertation (Master Degree), Universidade Federal de Lavras. Lavras, Minas Gerais, Brasil. 96p.

Santos, S. T., Vieira, L. P., Costa, J. P. B. M., Freitas, R. S., Regis, L. R. L. \& Oliveira, F. A. (2017). Produção de mudas de couve manteiga submetidas a diferentes concentrações de soluções nutritivas. Anais do IV INOVAGRI. INOVAGRI International Meeting. Fortaleza, Ceará, Brasil.

Santos, T. T. \& Varavallo, M. A. (2011). Aplicação de microrganismos endofíticos na agricultura e na produção de substâncias de interesse econômico. Semina: Ciências Biológicas e da Saúde, 32 (2), 199-212.

Seesuriyachan, P., Kuntiya, A., Hanmoungjai, P., Techapun, C., Chaiyaso, T. \& Leksawasdi, N. (2012). Optimization of exopolysaccharide overproduction by Lactobacillus confuses in solid state fermentation under high salinity stress. Bioscience Biotechnology and Biochemistry, 76 (5), $912-917$.

Serra, L. S., Mendes, M. R. F., Soares, M. V. A. \& Monteiro, I. P. (2016). Revolução Verde: Reflexões acerca da questão dos agrotóxicos. Revista Científica do Centro de Estudos em Desenvolvimento Sustentável da UNDB, 1 (4), 2-25.

Shingo, G. Y. \& Ventura, M. U. (2009). Produção de couve Brassica oleracea L. var. acephala com adubação mineral e orgânica. Semina: Ciências Agrárias, $30(3), 589-594$

Silva, C. S., Araújo, R. G. V., Lima, J. R. B., Santos, T. M. C., Nascimento, M. S., Montaldo, Y. C. \& Silva, J. M. (2019). Resistence induction in Brassica oleracea var. acephala to Xanthomonas campestris pv. campestris and growth promotion by endophytic. Brazilian Journal of Development, 5, (10), 2240122414.

Silva, C. S., Guedes, E. L. F., Santos, M. T., Montaldo, Y. C., Oliveira, J. U. L. \& Santos, T. M. C. 2018. Isolamento e seleção de bactérias endofíticas e rizosféricas de cactáceas em meio sob estresse hídrico. 29-31, Editora Blucher, São Paulo, São Paulo, Brasil.

Silva, C. S., Santos, J. M. C., Silva, J. M., Tenório, F. A., Celestino, E. L. F. G., Cristo, C. C. N., Nascimento, M. S., Montaldo, Y. C., Oliveira, J. U. L. \& Santos,T. M. C. (2019). Bioprospecting of endophytic bacteria (Bacillus spp.) from passionfruit (Passiflora edulis Sims f. flavicarpa) to plant growth promotion. Australian Journal of Crop Science, 8, 1369-1374.

Silva, C. S., Tenório, F. A., Silva, J. M., Guedes Celestino, E. L. F., Araújo, R. G. V., Lima, J. R. B., Montaldo, Y. C. \& Santos, T. M. C. (2018). Solubilização de fosfatos inorgânicos por bactérias endofíticas isoladas de maracujá amarelo (Passiflora edulis Sims f. flavicarpa). Revista Craibeiras de Agroecologia, 1 (1), 1-5.

Silva, C. S., Silva, J. M., Oliveira, J. U. L., Araújo, R. G. V., Lima, J. R. B., Guedes, E. L. F., Santos, M. T., Montaldo, Y. C. \& Santos, T. M. C. (2019). Bioprospecting rhizobacteria associated to cacti to water stress resistance and biofilm formation. Revista Brasileira de Gestão Ambiental e Sustentabilidade, 6 (14), 873-881.

Silva, J. M., Santos, T. M. C., Albuquerque, L. S., Montaldo, Y. C., Oliveira, J. U. L., Silva, S. G. M., Nascimento, M. S. \& Teixeira, R. R. O. (2015). Potential of endophytic bactéria (Herbaspirillum spp. and Bacillus spp.) to promote sugarcane growth. Australian Journal of Crop Science. 9 (8), 754-760.

Strobel, \&; Daisy, B. (2003). Bioprospecting for Microbial Endophytes and Their Natural Products. Microbiology and Molecular Biology Reviews, 67 (4), 491-502.

Sutherland, I. W. (1993). Xanthan. In: Swings, J. G. \& Civerolo, E. L. [eds.]. Xanthomonas. 363-388, Chapman \& Hall.

Takatsu, A. (2000). Classificação atual de bactérias fitopatogênicas. Revisão Anual de Patologia de Plantas, 8, 93-120.

Tessmann, C. (2002). Caracterização molecular de Xanthomonas campestris pv. pruni pela técnica de rapd e prognóstico da produção e qualidade da xantana. Dissertation (Master Degree) Universidade Federal de Pelotas. Pelotas, Rio Grande do Sul, Brasil. 46p.

Trani, P. A., Tivelli, S. W., Blat, S. F., Prela-Pantano, A., Teixeira, E. P., Araújo, H. S., Feltran, J. C., Passos, F. A., Figueiredo, G. J. B. \& Novo, M. C. S. S. (2015). Couve de folha: Do plantio à pós-colheita. Boletim Técnico 214 do Instituto Agronômico de Campinas - IAC, Campinas, São Paulo, Brasil, 36p.

Tybusch, J. S. \& Martins, E. J. (2016). Revolução Verde em ação versus Revolução Agroecológica em construção: Os direitos da agrobiodiversidade e os caminhos para a sustentabilidade. Anais do XXV Encontro Nacional do Conselho Nacional de Pesquisa e Pós-graduação em Direito - CONPEDI. Brasília, Distrito Federal, Brasil, 265-281.

Venieraki, A., Dimou, M., Pergalis, P., Kefalogianni, I., Chatzipavlidis, I. \& Katinakis, P. (2010). The genetic diversity of culturable nitrogen-fixing bactéria in the rhizosphere of wheat. Microbial Ecology, 61 (2), 277-285.

Vilela, N. J. \& Luengo, R. F. A. (2017). Produção de hortaliças folhosas no Brasil. Campo \& Negócios. Seção Hortifruti. Retrived from http:// revistacampoenegocios.com.br/producao-de-hortalicas-folhosas-no-brasil/

Volksch, B., Ullrich, M. \& Fritsche, W. (1992). Identification and population dinamics of bacteria in leaf spots of soybean. Microbial Ecology, 24 (3), 305311. 
Research, Society and Development, v. 10, n. 2, e33810212653, 2021

(CC BY 4.0) | ISSN 2525-3409 | DOI: http://dx.doi.org/10.33448/rsd-v10i2.12653

Williams, P. H. (1980). Black Rot: a continuing threat to world crucifers. Plant Disease, 64, 736-742.

Wruck, D. S. M., Oliveira, J. R. \& Dias, L. A. S. (2010). Especificidade de hospedeiro nas interações Xanthomonas campestris pv. campestris - brássicas. Summa Phytopathologica, 36 (2), 129-133.

Zanuncio Junior, J. S., Lazzarini, A. L., Oliveira, A. A., Rodrigues, L. A., Souza, I. I. M., Andrikopoulos, F. B., Fornazier, M. J. \& Costa, A. F. (2018). Manejo agroecológico de pragas: Alternativas para uma agricultura sustentável. Revista Científica Intelletto, 3 (3), 18-34. 